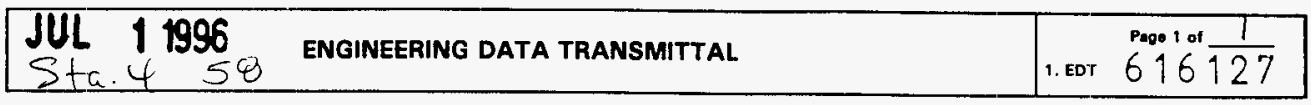

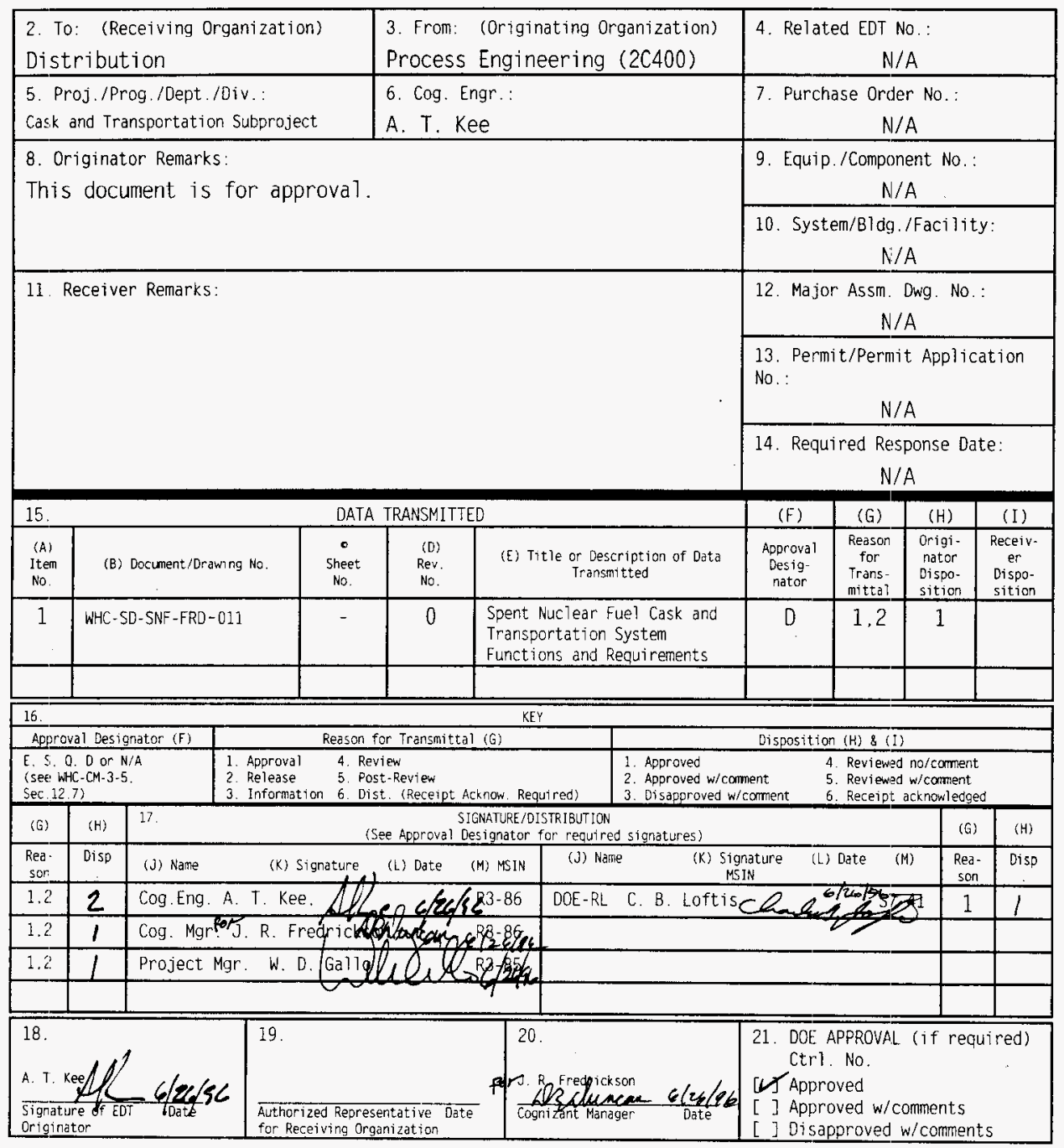

BD-7400-172-2 (04/94) GEF097 


\section{Spent Nuclear Fuel Cask and Transportation System Functions and Requirements}

\section{AT Kee}

Westinghouse Hanford Company, Richland. WA 99352

U.S. Department of Energy Contract DE-AC06-87RL10930

EDT/ECN: $616127 \quad$ UC:

Org Code: 2C400 Charge Code: LE002

B\&R Code: Total Pages: 21

Key Words: Cask. Transportation, CTS, Functions and Requirements, F\&R. Systems Engineering. Spent Nuclear Fuel, SNF

Abstract: This document provides the Functions and Requirements for the Spent Nuclear Fuel Cask and Transportation Subproject. It provide the requirements basis for the subproject to support conceptual and definitive designs.

TRADEMARK DISCLAIMER. Reference herein to any specific commercial product, process. or service by trade name, trademark, manufacturer. or otherwise, does not necessarily constitute or imply its endorsement. recommendation, or favoring by the United States Government or any agency thereof or its contractors or subcontractors.

Printed in the United States of America. To obtain copies of this document, contact: WHC/BCS Document Control Services. P.0. Box 1970. Mailstop H6-08. Richland WA 99352. Phone (509) 372-2420; Fax (509) 376-4989
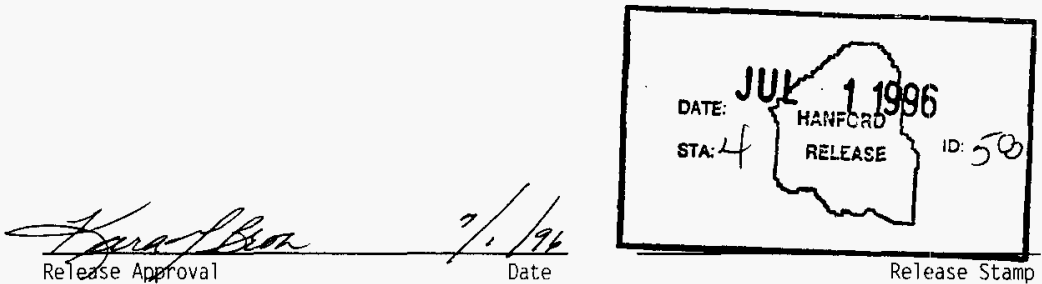

\section{Approved for Public Release}


WHC-SD-SNF-FRD-011

Revision 0

\title{
Spent Nuclear Fuel
}

\section{Cask and Transportation System \\ Functions \& Requirements}

\author{
Prepared for the \\ U.S. Department of Energy \\ Office of Environmental Restoration and Waste Management
}

\author{
Prepared by \\ Westinghouse Hanford Company \\ P.O. Box 1970 \\ Richland, WA 99352
}

Hanford Operations and Engineering Contractor for the

U.S. Department of Energy under Contract DOE-AC06-87RL10930 


\section{TABLE OF CONTENTS}

SECTION

PAGE

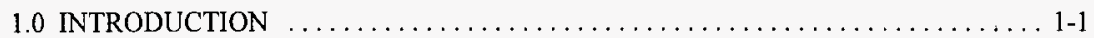

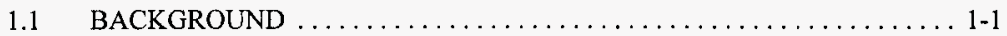

1.2 PURPOSE $\ldots \ldots \ldots \ldots \ldots \ldots \ldots \ldots \ldots \ldots \ldots \ldots \ldots \ldots \ldots \ldots \ldots \ldots \ldots, 1$

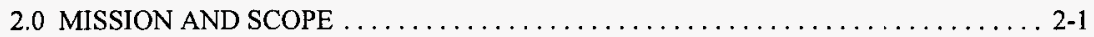

$2.1 \quad$ MISSION $\ldots \ldots \ldots \ldots \ldots \ldots \ldots \ldots \ldots \ldots \ldots \ldots \ldots \ldots \ldots \ldots \ldots \ldots \ldots, 1$

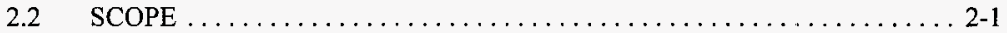

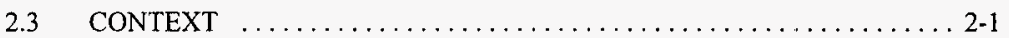

3.0 CASK \& TRANSPORTATION SYSTEM BACKGROUND $\ldots \ldots \ldots \ldots \ldots \ldots \ldots$ 3-1

4.0 RECOMMENDED PROCESS SEQUENCE AND INTERFACES $\ldots \ldots \ldots \ldots \ldots .4-1$

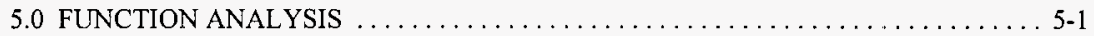

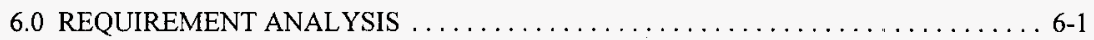

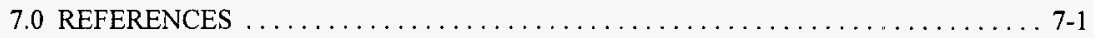

\section{LIST OF TABLES}

SECTION $\underline{\text { PAGE }}$

Table 1. Cask and Transportation System Function Definitions ............... 5-4

Table 2. Cask and Transportation System Requirement Sources ............... 6-2

\section{LIST OF FIGURES}

SECTION

PAGE

Figure 1. Cask and Transportation System Hardware Function Hierarchy $\ldots \ldots \ldots \ldots \ldots .5-2$

Figure 2. Cask and Transportation System Hardware Function Relationship to

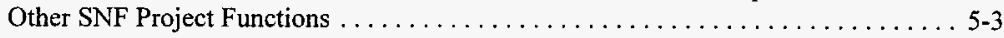




\section{ACRONYMS}

$\begin{array}{ll}\text { CSB } & \text { Canister Storage Building } \\ \text { F\&R(s) } & \text { Functions and Requirements } \\ \text { IPS } & \text { Integrated Process Strategy for K Basins SNF } \\ \text { MCO } & \text { Multi-Canister Overpack } \\ \text { PFD } & \text { Process Flow Diagram } \\ \text { SNF } & \text { Spent Nuclear Fuel }\end{array}$

\section{DEFINITIONS}

Canister. Metal (aluminum or stainless steel) container used to store reactor fuel rods/elements. Canisters containing fuel are configured in a double-barrel shape.

Cask. Container which provides shielding and containment for SNF during transfer.

Conditioning. Processing of SNF by physical, chemical or mechanical means to prepare the SNF to meet predetermined requirements for safe and compliant storage or disposal. Does not include packaging.

Confine. To retain the solid form of radioactive material inside a boundary.

Constraints. Restrictions or limitations that must be met. Constraints are used to screen alternative strategies and are always nontradeable by the designer (as opposed to requirements which are tradable).

Contain. To retain the solid and gaseous forms of radioactive material inside a boundary.

Contamination. Radioactive and/or other hazardous material in any place where it is not desired, particularly where its presence may be harmful.

Conveyance. Device used for transferring the package.

Decontamination. The activities employed to reduce the levels of radioactive and/or other hazardous contamination in or on structures, equipment, materials, and personnel.

Function. Specific actions, activities, or processes that achieve or support the achievement of the mission. That which must be achieved by the collective effects of all constituent parts. It is synonymous with "purpose."

Interface. System boundary across which material, data, and/or energy passes.

Load-Out Pit. The portion of the K Basin utilized for outloading of the fuel, fuel canisters, MCOs, and casks. 
Multi-Canister Overpack. Item that houses SNF in a configuration which is to be determined. Designed specifically for K Basin SNF only.

Package. SNF and its packaging.

Packaging. Material which provides containment and shielding (e.g., MCO and cask) for SNF.

Path Forward. Integrated activities to achieve a defined strategy for final disposition of SNF.

Requirement. Requirements define how well a function must perform. Requirements set limits on functions and also limits on the outputs from functions. A requirement is a description of a mandatory condition under which a function must be performed. Requirements are documented in technical specifications, statutes, regulations, Secretary of Energy Notices, DOE orders, Department of Energy Richland Operations Office (DOE-RL) Directives, or other official direction from the DOE customer.

Spent Nuclear Fuel. Nuclear fuel that has been withdrawn from a nuclear reactor following irradiation and the constituent elements that have not been separated by reprocessing.

Systems Engineering. The systematic approach used to transform technical goals and objectives into an optimized, operational, physical system that achieves its mission. The iterative technical and management process applied throughout a system life cycle that produces and maintains a well defined and documented system technical baseline.

Technical Baseline. The documented functions, requirements, and configuration from which the program will acquire an operational system. The technical baseline is maintained under configuration control, and is the basis for technical performance measurement.

Transfer. Movement of materials within the confines of the Hanford Site. 
WHC-SD-SNF-FRD-011 Rev. 0

\subsection{INTRODUCTION}

\subsection{BACKGROUND}

The Spent Nuclear Fuel Project Technical Baseline Document Fiscal Year 1996 (WHC 1995d) describes the mission and programmatic functions and requirements of the Spent Nuclear Fuel (SNF) Project. This latest revision includes changes made to the technical baseline as a result of incorporating the Integrated Process Strategy for K Basins Spent Nuclear Fuel (WHC 1995a) (IPS). The IPS contains the path forward for retrieval, containment, transfer, conditioning, and interim storage of SNF currently stored in the $\mathrm{K}$ Basins (excluding other Hanford Site SNF). The path forward projects include a fuel retrieval system, multi-cariister overpack, vacuum drying system, cask and transportation project, canister storage building, hot vacuum conditioning system, and water and sludge treatment process.

This document marks the departure point for all Cask and Transportation Subproject technical activities. This document further defines the overall SNF Project technical baseline by developing the lower tier hardware functions and requirements for the Cask and Transportation System. The technical functions and requirements establish the entire requirements basis for the Cask and Transportation Subproject.

\subsection{PURPOSE}

The Cask and Transportation Functions and Requirements (F\&Rs) document specifies the functions, requirements, and interfaces applicable throughout the life of the Cask and Transportation System. The Cask and Transportation F\&Rs also:

o Define the Cask and Transportation mission;

o Define the functions that the Cask and Transportation System needs to perform to accomplish its mission and document its requirements basis;

- Implement the requirements set forth in Section 2.1.1 of the Spent Nuclear Fuel Project Management Plan (WHC 1995b), which requires functions and requirements documents for each SNF Project Subproject;

o Establish the functional requirements baseline.

This document is organized in seven sections. Sections 1.0, Introduction, and 2.0, Mission and Scope, provide brief introductions to the document and the Cask and Transportation Subproject. Sections 3.0 through 6.0 provide the functional requirements baseline (Section 3.0 , Cask and Transportation System Background, 4.0, Recommended Process Sequence and Interfaces, 5.0, Function Analysis, and 6.0, Requirements Analysis). Section 7.0, References, lists all the sources referenced in this document. 


\subsection{MISSION AND SCOPE}

\subsection{MISSION}

The mission of the Cask and Transportation System has been derived from the Spent Nuclear Fuel Project Mission. In order to achieve the SNF Project mission, the scope of the Cask and Transportation Subproject must be completed. The Cask and Transportation Subproject is to:

- Provide shielding of the loaded $\mathrm{MCO}$;

- provide containment of the loaded MCO during transfer;

- transfer of the loaded MCO in the K Basins and to cold vacuum drying; and

- transfer of the loaded MCO to the Canister Storage Building (CSB)

The mission of the Cask and Transportation Subproject is to provide safe, economic and environmentally sound transfer of the SNF from the K Basins to the CSB.

\subsection{SCOPE}

The scope of the Cask and Transportation Subproject includes the definition and. acquisition of the cask, transportation system, and necessary support equipment to achieve the mission. The Cask and Transportation Subproject procures the cask, transportation system, and all necessary support equipment (excluding facility installed equipment at $\mathrm{K}$ Basins and the CSB). The acquisition of the Cask and Transportation System includes design, fabrication, test, production, qualification, documentation, and training for the Cask and Transportation System. Management of these activities and organizational relationships, roles, and responsibilities are further described in the Project W-443 Cask/Transportation Subproject, Project Management Plan (WHC, 1996a).

\subsection{CONTEXT}

The Spent Nuclear Fuel Project Technical Baseline Description Fiscal Year 1996 (WHC 1995d) contains the top-level functional breakdown for the SNF Project. The Cask and Transportation Subproject continues the functional breakdown of three of these SNF Project functions: Function 2.4.1.9 Provide Cask and Transportation System, Function 4.1.1.8.3.4 Prepare and Remove SNF, and Function 4.1.1.8.3.6 Transfer SNF. 


\subsection{CASK \& TRANSPORTATION SYSTEM BACKGROUND}

As the Spent Nuclear Fuel Project has matured, many decisions have been made which have affected the functions which the Cask and Transportation System must perform. These have been developed through numerous studies, assessments and decision documents. These documents include the following:

- Independent Technical Assessment, Dry Storage of N Reactor Fuel, (ITA 1994a)

- $\quad$ Trade Study for K Basin Spent Nuclear Fuel Removal and Conditioning,(Parsons 1995a)

- Hanford Spent Nuclear Fuel Project Recommended Path Forward, (WHC 1994a)

- Integrated Process Strategy for K Basins Spent Nuclear Fuel, (WHC 1995a)

This document reflects the current configuration as documented in the SNF Project documentation and the integrated process strategy. It has been determined from these studies that the Cask and Transportation Subproject shall provide the functions further described in Section 5.0 of this document. 


\subsection{RECOMMENDED PROCESS SEQUENCE AND INTERFACES}

The Cask and Transportation Subproject supports several activities and functions within the SNF Project. Many of these functions are not within the scope of the Cask and Transportation Subproject. As a result, the Cask and Transportation Subproject has many interfaces. These interfaces are identified in Interface Agreement Coversheet/ Interface Scope Sheets and are further defined by Interface Control Sheets. Interface Control will be accomplished and maintained as described in the Spent Nuclear Fuel Project Interface Control Plan (WHC 1995h). and Facilities:

The Cask and Transportation Subproject interfaces with the following SNF Subprojects

- Fuel Retrieval Subproject

- Multi-Canister Overpack

- Cold Vacuum Drying facility and systems

- Canister Storage Building

o $\quad$ K Basin Operations

Each physical interface is defined in detail on an Interface Control Sheet. These sheets are controlled, and maintain the current interface information. 


\subsection{FUNCTION ANALYSIS}

Systems engineering analysis decomposed and tailored the SNF Project functions identified in Section 2.3 and the Spent Nuclear Fuel Project Technical Baseline Document Fiscal Year 1996 (WHC 1995d) to establish hierarchy and define lower-tier functions that need to be performed to accomplish the mission of the Cask and Transportation Subproject. The functional breakdown for the Cask and Transportation Subproject is traceable to the SNF Project functional breakdown and in turn to the Hanford Site functional breakdown. The function breakdown for the Cask and Transportation Subproject is shown in:

- Figure 1, Cask and Transportation System Hardware Function Hierarchy, which shows the functions to be performed by the Cask and Transportation System

- Figure 2, Cask and Transportation System Hardware Function Relationship to Other SNF Project Functions, which shows the relationship of the Cask and Transportation. System hardware functions to the SNF Project functions.

The function definitions for the Cask and Transportation System are contained in Table 1, Cask and Transportation System Function Definitions. Cask and Transportation System functions shown on Figure 1 are hardware functions and are labeled as CTS-F-X.X to denote this distinction. 
Figure 1. Cask and Tranportation System Hardware Function Hierarchy

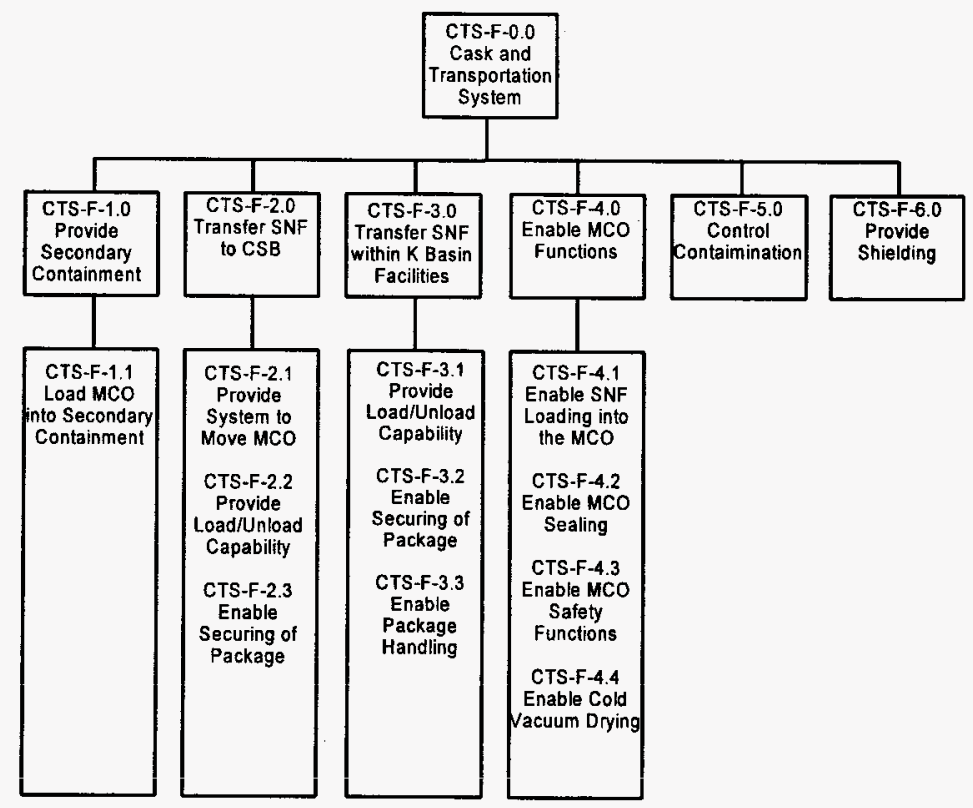




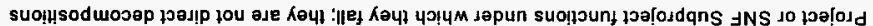

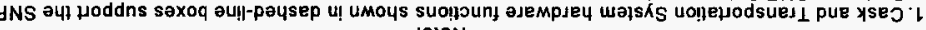

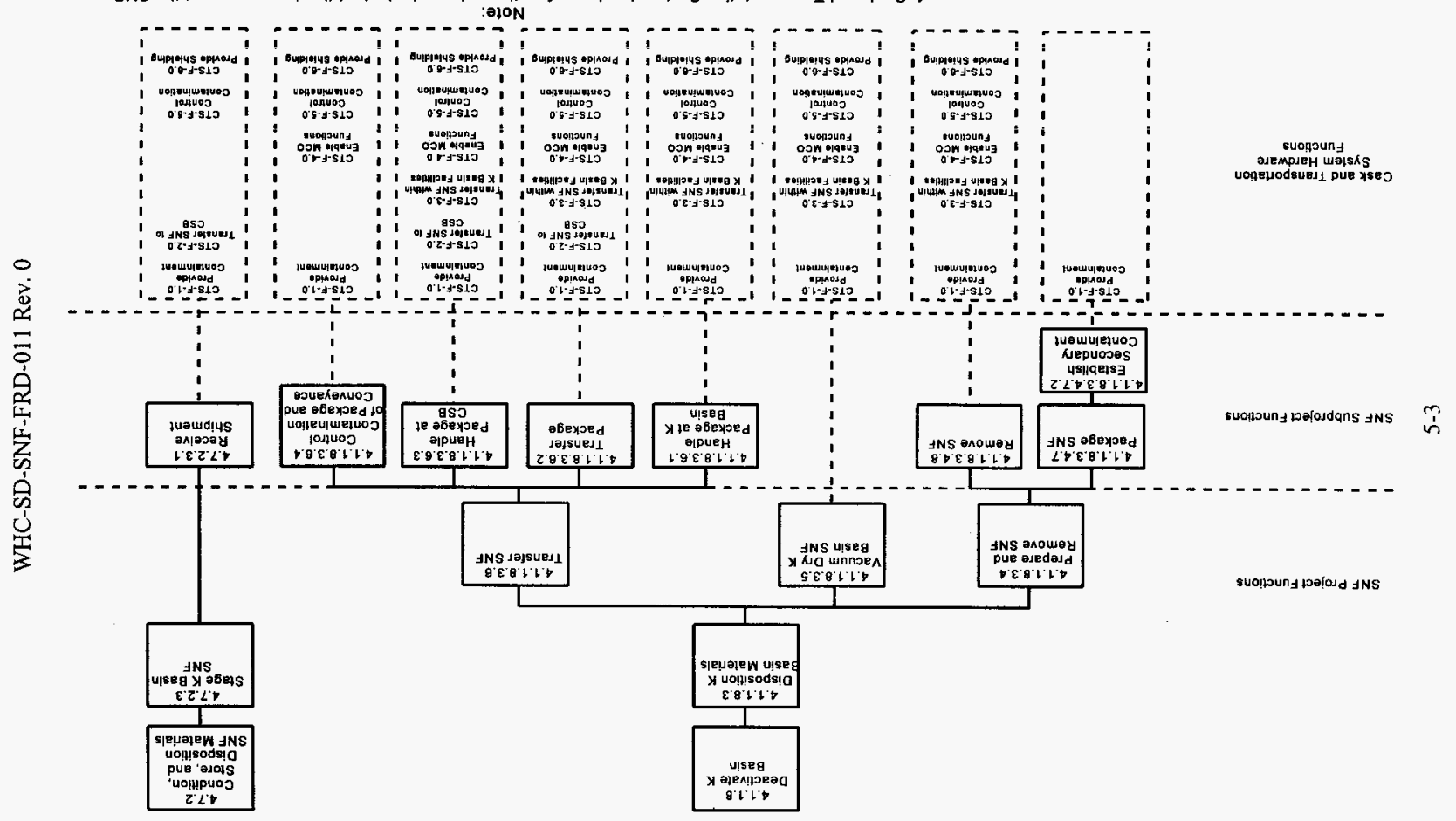

suo!̣oung foolodd $\exists N S$ saulo of d! ' 2 องn6! 与 
Table 1. Cask and Transportation System Function Definitions.

\begin{tabular}{|c|c|}
\hline Function Number & Function Title and Definition \\
\hline $\begin{array}{l}2.4 .1 .9^{*} \\
\text { (SNF Project Function) }\end{array}$ & $\begin{array}{l}\text { Provide Cask and Transportation System. } \\
\text { Define, design, fabricate, construct, procure, test, and accept Cask Transportation equipment and } \\
\text { procedures. }\end{array}$ \\
\hline $\begin{array}{l}\text { 4.1.1.8.3.4* } \\
\text { (SNF Project Function) }\end{array}$ & $\begin{array}{l}\text { Prepare and Remove SNF. } \\
\text { Obtain the Multi-Canister Overpack (MCO) including the MCO rerack baskets. Retrieve the canisters, } \\
\text { separate the SNF from the canisters, clean and rerack the SNF and load the MCO rerack baskets into the } \\
\text { MCO. Seal MCO, load into cask, and transfer to vacuum drying module. }\end{array}$ \\
\hline $4.1 .1 .8 .3 .4 .7^{*}$ & $\begin{array}{l}\text { Package SNF } \\
\text { Establish primary and secondary containment for SNF during preparation and removal of SNF from the K } \\
\text { Basin, vacuum drying of SNF, and transportation of SNF to the CSB. }\end{array}$ \\
\hline $4.1 .1 .8 .3 .4 .7 .2^{*}$ & $\begin{array}{l}\text { Establish Secondary Containment Containment. } \\
\text { Provide containment boundary for SNF during normal conditions of transportation. }\end{array}$ \\
\hline $\begin{array}{l}\text { 4.1.1.8.3.6* } \\
\text { (SNF Project Function) }\end{array}$ & $\begin{array}{l}\text { Transfer SNF } \\
\text { Obtain Cask and Transportation Vehicle, load and ship the MCO containing cold-vacuum dried SNF to the } \\
\text { Canister Storage Building. }\end{array}$ \\
\hline $4.1 .1 .8 .3 .6 .1^{*}$ & $\begin{array}{l}\text { Handle Package at K Basin. } \\
\text { Move a package from a staging area within the } \mathrm{K} \text { Basin facility onto the conveyance and move an empty } \\
\text { package off the conveyance to the staging area. }\end{array}$ \\
\hline 4.1.1.8.3.6.2* & $\begin{array}{l}\text { Transfer Package. } \\
\text { Transfer the full or empty package between the K Basin facility, the Vacuum Drying Module, and the CSB. }\end{array}$ \\
\hline
\end{tabular}

*Not all activities described within this function apply to the Cask and Transportation Subproject. 
Table 1. Cask and Transportation System Function Definitions.

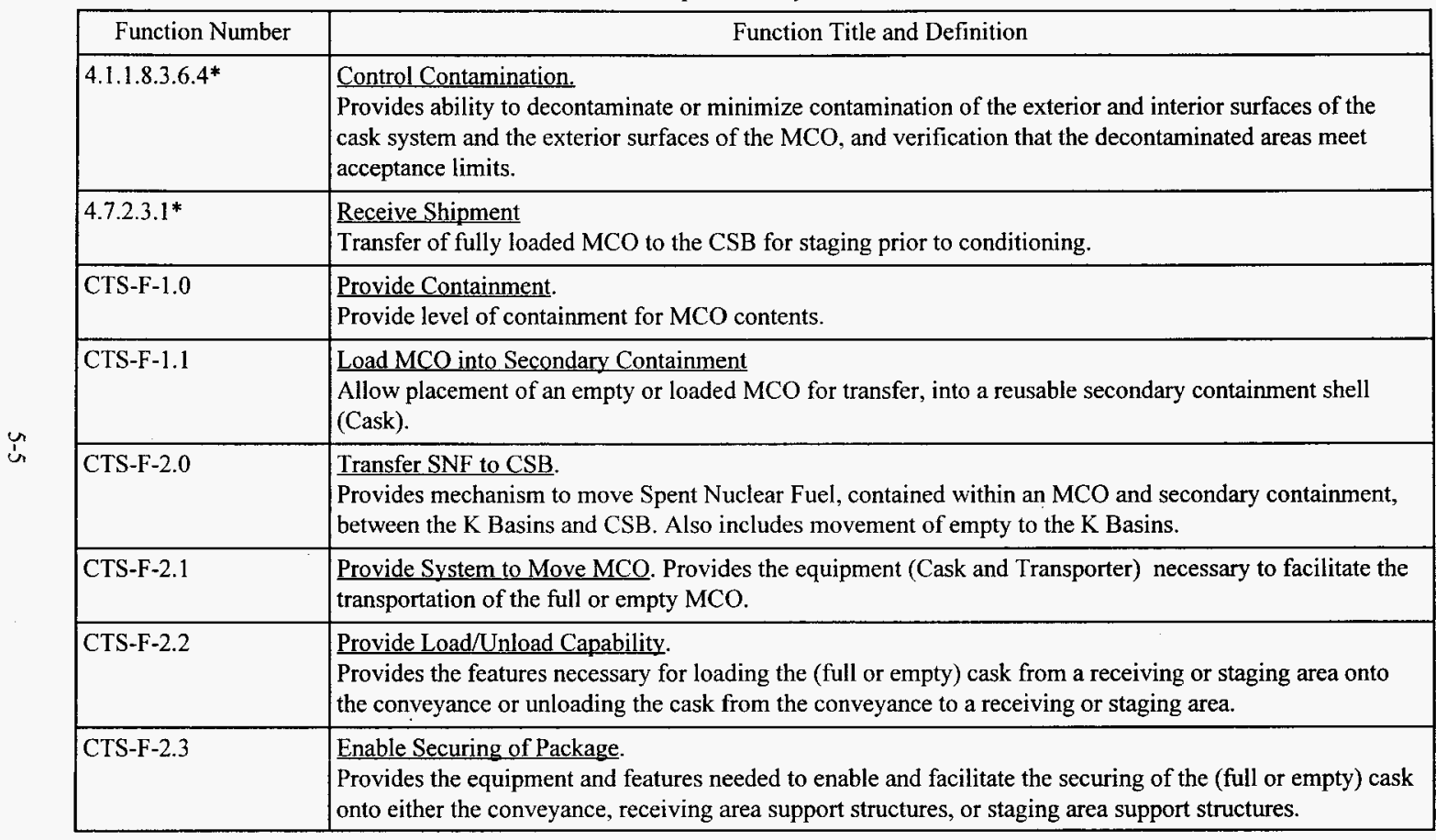


Table 1. Cask and Transportation System Function Definitions.

\begin{tabular}{|c|c|}
\hline Function Number & Function Title and Definition \\
\hline CTS-F-3.1 & $\begin{array}{l}\text { Provide Load/Unload Capability. } \\
\text { Furnishes the features necessary for loading the (full or empty) cask onto the conveyance, receiving area, or } \\
\text { staging area, also includes unloading the full or empty cask. }\end{array}$ \\
\hline CTS-F-3.2 & $\begin{array}{l}\text { Enable Securing of Package. } \\
\text { Provides the equipment and features needed to enable and facilitate the securing of the (full or empty) cask } \\
\text { onto the transfer equipment. }\end{array}$ \\
\hline CTS-F-4.0 & $\begin{array}{l}\text { Enable MCO Functions. } \\
\text { Provides a configuration which to allows the MCO to achieve the functions of loading, containment, } \\
\text { confinement, maintain critically safe, vacuum drying, safety functions and transfer of SNF, which are } \\
\text { provided for by the MCO subproject. }\end{array}$ \\
\hline CTS-F-4.2 & $\begin{array}{l}\text { Enable MCO Sealing. } \\
\text { Provides a configuration to allow the sealing of the MCO while contained in the cask system. MCO sealing } \\
\text { will be provided for by the MCO subproject. }\end{array}$ \\
\hline CTS-F-4.3 & $\begin{array}{l}\text { Enable MCO Safety Functions. } \\
\text { Provides configuration necessary to enable venting, inerting, purging and pressure relief of the MCO, } \\
\text { which is provided for by the MCO. }\end{array}$ \\
\hline $\mathrm{CTS}=\mathrm{F}=4.4$ & $\begin{array}{l}\text { Enable Cold Vacuum Drying. } \\
\text { Provides the ability for the MCO to be cold vacuum dried while in the cask. }\end{array}$ \\
\hline
\end{tabular}


Table 1. Cask and Transportation System Function Definitions.

\begin{tabular}{|l|l|}
\hline \multicolumn{1}{|c|}{ Function Number } & \multicolumn{1}{c|}{ Function Title and Definition } \\
\hline CTS-F-5.0 & $\begin{array}{l}\text { Control Contamination. } \\
\text { Provides ability to decontaminate or minimize contamination of the exterior and interior surfaces of the } \\
\text { cask system and the exterior surfaces of the MCO, and verification that the decontaminated areas meet } \\
\text { acceptance limits. }\end{array}$ \\
\hline CTS-F-6.0 & $\begin{array}{l}\text { Provide Shielding. } \\
\text { Provide radiation shielding during transfer and temporary storage of the MCO. }\end{array}$ \\
\hline
\end{tabular}




\subsection{REQUIREMENT ANALYSIS}

Requirements have been imposed on the Cask and Transportation Subproject as a result of the requirements allocation process which has been applied to the SNF Project requirements basis. The SNF Project requirements basis represents constraints imposed against the Hanford Site that are passed on to SNF Project functions, including the SNF Project Functions 2.4.1.9 Provide Cask and Transportation System and 4.1.1.8.3.6 Transfer SNF, which are performed solely by the Cask and Transportation Subproject, and SNF Project Function 4.1.1.8.3.4. Prepare and Remove SNF, which is performed partially by the Cask and Transportation System.

Table 2 provides a list of source documents which have been found to contain requirements that may apply to the Cask and Transportation Subproject. These sources will be analyzed and the specific requirements will be incorporated into specifications and design documents as applicable. When conflicting or contradictory requirements are found, the design authority will select the preferred requirement or generate a derived requirement. 
WHC-SD-SNF-FRD-011, Rev.0

Table 2. Cask and Transportation System Requirement Sources

\section{TECHNICAL REQUIREMENTS}

Requirement Reference:

10 CFR 71 - Packaging and Transportation of Radioactive Materials

10 CFR 72 - Licensing Requirements for the Independent Storage of Spent Nuclear Fuel and High-Level Radioactive Waste

10 CFR 830.120 - Quality Assurance Requirements

10 CFR 835 - Occupational Radiation Protection

29 CFR 1910 - Occupational Safety and Health Protection Standards

40 CFR 191 - Environmental Radiation Protection Standards for Management and Disposal of Spent Nuclear Fuel, High Level and Transuranic Radioactive Waste

49 CFR 172 - Dimensional Specifications for Recommended Placard Holder

49 CFR 173 - Shippers - General Requirements for Shipments and Packaging

49 CFR 393 - Parts and Accessories Necessary for Safe Operation

49 CFR 397 - Transportation of Hazardous Materials: Driving and Parking Rules

49 CFR 571 - Federal Motor Vehicle Safety Standards

RCW 46.37 - Vehicle Lighting and Other Equipment

RCW 46.44 - Size, Weight, Load

WAC 446-50 - Transport of Hazardous Materials

WAC 470-12 - Transporting Rules

SEN-35-91 - Nuclear Safety Policy

DOE Order 1300.2A - Department of Energy Technical Standards Program

DOE Order 1540.1A - Material Transportation and Traffic Management

DOE Order 1540.2 - Hazardous Material Packaging for Transport - Administrative Procedures

DOE Order 1540.3A - Base Technology for Radioactive Material Transportation Packaging Systems

DOE Order 4330.4B - Maintenance Management Program 


\section{TECHNICAL REQUIREMENTS}

DOE Order 4700.1 - Project Management System

DOE Order 5400.1 - General Environmental Protection Program

DOE Order 5400.5 - Radiation Protection of the Public and the Environment

DOE Order 5480.3 - Safety Requirements for the Packaging and Transportation of Hazardous Materials, Hazardous Substances, and Hazardous Wastes

DOE Order 5480.4 - Environmental Protection, Safety, and Health Protection Standards

DOE Order 5480:11 - Radiation Protection for Occupational Workers

DOE Order 5480.22 - Technical Safety Requirements

DOE Order 5480.23 - Nuclear Safety Analysis Reports

DOE Order 5480.24 - Nuclear Criticality Safety

DOE Order 5630.11B - Safeguards and Security Program

DOE Order 5700-6C - Quality Assurance

RLID 5632.1B - Asset Protection requirements

HSRCM-1 - Hanford Site Radiological Control Manual

SNF-RD-PM-001 Rev. 0 - Spent Nuclear Fuel Program Requirements Document

DOE/RL-93-102 - Fiscal Year 1995 Hanford Mission Plan, Volume 1, Site Guidance, September 1994

WHC-CM-2-14 - Hazardous Material Packaging and Shipping

WHC-CM-4-2 - Quality Assurance Manual

WHC-CM-4-3 - Industrial Safety Manual

WHC-CM-4-14 - Applied Radiological Controls

WHC-CM-4-29 - Nuclear Criticality Safety Manual

WHC-CM-4-35 - Safeguards Material Control Manual

WHC-CM-4-50 - Safeguards Accounting Manual 
WHC-SD-SNF-FRD-011, Rev.0

\begin{tabular}{||l|l||}
\hline $\begin{array}{c}\text { REQMT } \\
\text { No. }\end{array}$ & \multicolumn{1}{c|}{$\begin{array}{c}\text { TECHNICAL } \\
\text { REQUIREMENTS }\end{array}$} \\
\hline & $\begin{array}{l}\text { WHC-CM-5-13 K Basin Policy Manual } \\
\text { WHC-CM-8-9 - Workmanship Standards } \\
\text { WHC-IP-0565 - Safeguards Desk Procedures } \\
\text { WHC-EP-0722 - Systems Engineering Functions and Requirements for the } \\
\text { Hanford Cleanup Mission: First Issue } \\
\text { WHC-EP-0779- Architecture Synthesis Basis for the Hanford Cleanup System } \\
\text { ANSL/ANS-8.1 - Nuclear Criticality Safety in Operations with Fissionable } \\
\text { Materials Outside Reactors }\end{array}$ \\
\hline
\end{tabular}




\section{WHC-SD-SNF-FRD-011, Rev.0}

\subsection{REFERENCES}

ITA, 1994a, Independent Technical Assessment (ITA), Dry Storage of N Reactor Fuel, September 1994, 2 vols., for U.S. Department of Energy - Richland Operations Office, Richland, Washington.

Parsons, 1995a, Trade Study for K Basin Spent Nuclear Fuel Removal and Conditioning, Revision 0, 4 vols., for Westinghouse Hanford Company, Richland, Washington.

WHC, 1994a, Hanford Spent Nuclear Fuel Project Recommended Path Forward, Revision 0, WHC-EP-0830, 2 vols., Westinghouse Hanford Company, Richland, Washington.

WHC, 1994b, Spent Nuclear Fuel Project Technical Baseline Document, WHC-SD-SNF-SD002, 4 vols., Westinghouse Hanford Company, Richland, Washington.

WHC, 1995a, Integrated Process Strategy for K Basins Spent Nuclear Fuel, WHC-SD-SNF-SP005, Westinghouse Hanford Company, Richland, Washington.

WHC, 1995b, Spent Nuclear Fuel Project Project Management Plan, WHC-SD-SNF-PMP-011, Westinghouse Hanford Company, Richland, Washington.

WHC, 1995c, Spent Nuclear Fuel Project Systems Engineering Management Plan, WHC-SDSNF-SEMP-001, Westinghouse Hanford Company, Richland, Washington.

WHC, 1995d, Spent Nuclear Fuel Project Technical Baseline Description Fiscal Year 1996, WHC-SD-SNF-SD-005, 2 vols., Westinghouse Hanford Company, Richland, Washington.

WHC, 1995e, Spent Nuclear Fuel Project Technical Baseline Document Fiscal Year 1995, WHC-SD-SNF-SD-003, 2 vols., Westinghouse Hanford Company, Richland, Washington.

WHC, 1995f, Spent Nuclear Fuel Interface Control Plan, WHC-SD-SNF-CM-003, Westinghouse Hanford Company, Richland Washington.

WHC, 1996a, Project W-443, Cask/Transportation Subproject Project Management Plan, WHCSD-W443-PMP-001, Westinghouse Hanford Company, Richland Washington. 